\title{
The Variations in the Soil Enzyme Activity, Protein Expression, Microbial Biomass, and Community Structure of Soil Contaminated by Heavy Metals
}

\author{
Xi Zhang, ${ }^{1}$ Feng Li, ${ }^{1,2}$ Tingting Liu, ${ }^{1}$ Chen Xu, ${ }^{1}$ Dechao Duan, ${ }^{1}$ Cheng Peng, \\ Shenhai Zhu, ${ }^{1}$ and Jiyan Shi ${ }^{1}$ \\ ${ }^{1}$ Institute of Environmental Science and Technology, Zhejiang University, Hangzhou, Zhejiang 310058, China \\ ${ }^{2}$ College of Materials and Environmental Engineering, Hangzhou Dianzi University, Hangzhou, Zhejiang 310018, China
}

Correspondence should be addressed to Jiyan Shi; shijiyan@zju.edu.cn

Received 20 October 2013; Accepted 11 November 2013

Academic Editors: W. Peijnenburg, D. G. Strawn, and J. Thioulouse

Copyright $\odot 2013 \mathrm{Xi}$ Zhang et al. This is an open access article distributed under the Creative Commons Attribution License, which permits unrestricted use, distribution, and reproduction in any medium, provided the original work is properly cited.

\begin{abstract}
Heavy metals have adverse effects on soil ecology. Given the toxicity of heavy metals, there is an urgent need to select an appropriate indicator that will aid in monitoring their biological effects on soil ecosystems. By combining different monitoring techniques for various aspects of microbiology, the effects of heavy metals on soil microorganisms near a smelter were studied. Our goal was to determine whether proteins could be a proper indicator for soil pollution. This study demonstrated that the activities of acid phosphatase and dehydrogenase, as well as the levels of microbial biomass carbon and proteins, were negatively affected by heavy metals. In addition, significantly negative correlations were observed between these microbial indicators and heavy metals. Denaturing gradient gel electrophoresis analysis was used in this study to demonstrate that heavy metals also have a significantly negative effect on soil microbial diversity and community structure. The soil protein expression was similar across different soils, but a large quantity of presumably low molecular weight protein was observed only in contaminated soil. Based on this research, we determined that the soil protein concentration was more sensitive to heavy metals than acid phosphatase, dehydrogenase, or microbial biomass carbon because it was more dramatically decreased in the contaminated soils. Therefore, we concluded that the soil protein level has great potential to be a sensitive indicator of soil contamination. Further research is essential, particularly to identify the low molecular weight protein that only appears in contaminated soil, so that further insight can be gained into the responses of microbes to heavy metals.
\end{abstract}

\section{Introduction}

Heavy metals (e.g., $\mathrm{Cd}, \mathrm{Cr}, \mathrm{Cu}, \mathrm{Pb}$, and $\mathrm{Zn}$ ) can be introduced into soils from several sources, such as waste from mines and smelters, atmospheric deposition, animal manures, sewage sludge, and, in some circumstances, inorganic fertilizer. Once these elements enter the soil, they can remain for extremely long periods and are difficult to remove [1]. Heavy metals are known to be toxic to most organisms when present in excessive concentrations [2]. Given the toxicity of these elements, there is an urgent need to monitor their biological effects on soil ecosystems.

Soil microbes play vital roles in the recycling of plant nutrients, the maintenance of soil structure, and the detoxification of poisonous chemicals [3]. Therefore, the diversity of microbial communities and the activity of microorganisms are important indicators of soil quality. Alterations in the composition of microbial communities have often been considered effective indicators for soil contamination [4]. Many reports have shown that either longterm or short-term exposure of soil to heavy metals results in a reduction of microbial diversity and microorganism activities $[3,5]$.

Although soil enzyme activity and microbial biomass are the most tested parameters in soil quality monitoring, these parameters still have many limitations $[2,6]$. They need to be supplemented by other valid microbial indicators, working together to fully assess soil contamination. The recent 
emergence of soil proteomics could provide a new perspective on soil microbial activities [7]. Proteins are the chief actors in organism metabolism processes, and they fall into a variety of categories; for example, enzymes are proteins with a catalytic function. Proteins work together to complete various biological functions. Soil proteins primarily come from microorganisms as well as from flora and fauna tissues. The structure of the microbial community, biomass, and microbial status often determine the synthesis levels of soil proteins. Therefore, any change to the microbial composition, which can be caused by environmental changes such as contamination, could reflect in the composition and expressions of soil proteins [8]. Soil proteomics studies aim to investigate the spatial and temporal changes of proteins extracted from soils because proteins are the functional components of the microbial genomic expression products. Such studies more conclusively determine the ecological functions of soil microbes and their roles in soil pollutant transportation and transformation [9-11]. Therefore, proteomics analyses have great potential in soil pollution assessment.

Currently, soil proteomics are predominantly used in studies of the biogeochemical cycle [12-14] and the rhizosphere soil microecosystem $[15,16]$. However, there is little literature on the monitoring of contaminated soil, and the existing studies were all carried out under controlled conditions $[8,17]$. Unlike a controlled laboratory, natural soil is a complicated ecosystem, and various factors combine to influence the transportation and transformation of pollutants as well as the structure of the microorganism community. Consequently, we were interested in examining the modification of soil proteins under heavy metals stress and determining whether proteins can be a useful indicator of natural soil pollution.

In this study, a typical heavy metal smelter was selected. We intended to study the effects of heavy metals on soil microbes by combining different biochemical analysis techniques. Three compounds were used for heavy metal extraction, $\mathrm{CaCl}_{2}$, EDTA, and DTPA, to assess the bioavailability of trace metals in soil $[18,19]$. Soil microbiological and biochemical properties (including enzyme activities, protein contents, and microbial biomass carbon levels) were measured to evaluate the effects of heavy metals. A soil microbial community analysis was carried out using molecular biology techniques. Partial 16S rDNA genes were amplified from soil microorganism community DNA by the polymerase chain reaction (PCR), using primers that bind to evolutionarily conserved regions within the bacteria and actinomycete genes. The diverse PCR amplified products were transformed to genetic fingerprints using denaturing gradient gel electrophoresis (DGGE) $[3,20]$. The soil protein composition was analyzed by SDS-polyacrylamide gel electrophoresis (SDSPAGE) [7].

\section{Materials and Methods}

2.1. Soil Research Region and Soil Sampling. The soil area selected for study is downwind of a copper-zinc smelter in Fuyang County, Zhejiang Province, China. The soil in the area has been contaminated by heavy metals, primarily $\mathrm{Cu}$ and $\mathrm{Zn}$. This area was formerly used to cultivate crops. Soil samples were taken in April 2012 at nine points along a pollution gradient of $\mathrm{Cu}$ and $\mathrm{Zn}$ (Table 1). At each point, three replicated samples were taken, and each sample was composed of three soil cores $5 \mathrm{~cm}$ in diameter and $20 \mathrm{~cm}$ in depth (approximately 500 g). Samples were taken randomly from different areas at each site. Each replicate soil sample was homogenized thoroughly. The site 2,000 $\mathrm{m}$ away from the smelter was chosen as the reference site, and the soil collected from it was marked "CK."

2.2. Sample Treatment and Analysis. Fresh soil samples were sieved $(\Phi \leq 2 \mathrm{~mm}$ ) by a nylon sieve to remove stones, large pieces of plant material, and soil animals. Portions of the samples were kept moist in the dark at $4^{\circ} \mathrm{C}$ to determine the microbial biomass and then stored at $-70^{\circ} \mathrm{C}$ to extract soil DNA. Other portions were freeze-dried and passed through a $0.25 \mathrm{~mm}$ nylon sieve prior to soil protein extraction. The remaining soil was air-dried under cool conditions (approximately $20^{\circ} \mathrm{C}$ ), sieved through a $0.25 \mathrm{~mm}$ nylon sieve, and stored at $4^{\circ} \mathrm{C}$ to analyze the enzyme activity, soil $\mathrm{pH}$, organic matter, total heavy metals, and bioavailable heavy metals.

The soil $\mathrm{pH}$ was determined with distilled water in a ratio (soil: water) of $1: 2.5(\mathrm{w} / \mathrm{v})$ using a $\mathrm{pH}$ meter (Orion 5-Star, Thermo). The soil was heated at $105^{\circ} \mathrm{C}$ for $12 \mathrm{~h}$ and then combusted at $550^{\circ} \mathrm{C}$ overnight to measure the organic matter content [21]. The samples were digested using the method described by Tang et al. [22]. The dry sample $(0.2 \mathrm{~g})$ was weighed and digested with a mixture of nitric acid $\left(\mathrm{HNO}_{3}\right)$, hydrofluoric acid ( $\left.\mathrm{HF}\right)$, and perchloric acid $\left(\mathrm{HClO}_{4}\right)$. The total concentrations of $\mathrm{Cd}, \mathrm{Cr}, \mathrm{Cu}, \mathrm{Pb}$, and $\mathrm{Zn}$ were measured by flame atomic absorption spectrometry (MKIL-M6, Thermo).

The soil bioavailable heavy metal fractions were estimated by extraction with $0.01 \mathrm{M} \mathrm{CaCl}_{2}$ (soil : solution, $1: 5$ ), $0.05 \mathrm{M}$ EDTA (soil:solution, 1:5), and DTPA (0.005 M DTPA, $0.01 \mathrm{M} \mathrm{CaCl}$, and $0.1 \mathrm{M}$ TEA at $\mathrm{pH}$ 7.3) (soil:solution, $1: 2.5$ ). The soil suspensions were shaken at $200 \mathrm{rpm}$ for $2 \mathrm{~h}$, centrifuged at $4,000 \times \mathrm{g}$ for $10 \mathrm{~min}$, and filtered [23-25]. The $\mathrm{Cd}, \mathrm{Cr}, \mathrm{Cu}, \mathrm{Pb}$, and $\mathrm{Zn}$ contents of the bioavailable fraction in each filtrate were determined by flame atomic absorption spectrometry.

2.3. Enzyme Activity Determination. We chose acid phosphatase and dehydrogenase as the subjects for our investigation of enzyme changes under heavy metal stress because they are closely related to the soil phosphorous cycle and to microbial metabolic activities $[26,27]$. To determine acid phosphatase activity, dry soil was incubated in disodium phenyl phosphate for $2 \mathrm{~h}$, and the results are expressed as the micrograms of $\mathrm{P}_{2} \mathrm{O}_{5}$ released per $100 \mathrm{~g}$ of dry soil using 4-aminoantipyrine colorimetry at $510 \mathrm{~nm}$. To measure dehydrogenase activity, dry soil was incubated in triphenyltetrazolium chloride (TTC) for $24 \mathrm{~h}$, and the results are expressed as the micrograms of triphenyl formazan (TPF) released per $1 \mathrm{~g}$ of dry soil. The concentration of TPF in the extract was measured using a colorimeter at $485 \mathrm{~nm}[27,28]$. 
TABLE 1: Selected soil physicochemical properties and the soil concentrations of heavy metals.

\begin{tabular}{|c|c|c|c|c|c|c|c|c|c|c|c|c|}
\hline \multirow{3}{*}{ Soil number } & \multicolumn{3}{|c|}{$\mathrm{CK}$} & \multicolumn{9}{|c|}{ Distance from the smelter } \\
\hline & \multirow[b]{2}{*}{1} & \multirow[b]{2}{*}{2} & \multirow[b]{2}{*}{3} & \multicolumn{3}{|c|}{$800 \mathrm{~m}$} & \multicolumn{3}{|c|}{$400 \mathrm{~m}$} & \multicolumn{3}{|c|}{$200 \mathrm{~m}$} \\
\hline & & & & 1 & 2 & 3 & 1 & 2 & 3 & 1 & 2 & 3 \\
\hline $\mathrm{pH}$ & 5.94 & 5.76 & 5.72 & 7.57 & 7.34 & 6.23 & 6.61 & 8.00 & 6.56 & 6.52 & 6.95 & 7.10 \\
\hline Organic matter (\%) & 4.76 & 5.36 & 4.69 & 4.06 & 4.64 & 3.23 & 6.84 & 5.42 & 6.21 & 7.65 & 6.78 & 6.13 \\
\hline \multicolumn{13}{|l|}{$\mathrm{Cu}\left(\mathrm{mg} \cdot \mathrm{kg}^{-1}\right)$} \\
\hline $\mathrm{CaCl}_{2}$ & 0.10 & 0.05 & 0.05 & 0.17 & 0.28 & 0.17 & 0.68 & 0.68 & 0.33 & 1.54 & 0.81 & 0.65 \\
\hline DTPA & 4.45 & 4.78 & 5.16 & 33.41 & 48.67 & 21.59 & 124.29 & 85.39 & 102.08 & 138.29 & 129.54 & 110.12 \\
\hline EDTA & 8.13 & 8.05 & 8.72 & 83.51 & 107.06 & 36.40 & 200.03 & 143.65 & 154.78 & 293.92 & 238.30 & 200.66 \\
\hline Total & 52 & 46 & 46 & 314 & 414 & 175 & 711 & 746 & 511 & 1147 & 794 & 624 \\
\hline \multicolumn{13}{|l|}{$\mathrm{Zn}\left(\mathrm{mg} \cdot \mathrm{kg}^{-1}\right)$} \\
\hline $\mathrm{CaCl}_{2}$ & 0.96 & 0.93 & 1.14 & 0.46 & 0.44 & 5.93 & 12.32 & 8.44 & 8.74 & 46.02 & 20.69 & 13.48 \\
\hline DTPA & 3.44 & 3.75 & 4.46 & 18.36 & 25.56 & 17.83 & 55.86 & 62.40 & 41.71 & 179.49 & 148.50 & 139.94 \\
\hline EDTA & 5.33 & 5.69 & 6.77 & 43.45 & 63.33 & 30.84 & 75.43 & 121.80 & 63.59 & 680.38 & 394.31 & 468.81 \\
\hline Total & 116 & 113 & 111 & 260 & 364 & 187 & 599 & 596 & 545 & 2472 & 1456 & 1421 \\
\hline \multicolumn{13}{|l|}{$\mathrm{Pb}\left(\mathrm{mg} \cdot \mathrm{kg}^{-1}\right)$} \\
\hline $\mathrm{CaCl}_{2}$ & 0.60 & 0.65 & 0.57 & 0.59 & 0.59 & 0.57 & 0.58 & 0.59 & 0.63 & 0.70 & 0.61 & 0.60 \\
\hline DTPA & 3.38 & 4.21 & 4.25 & 6.46 & 13.06 & 5.58 & 25.79 & 89.79 & 23.99 & 71.09 & 101.70 & 78.98 \\
\hline EDTA & 8.60 & 9.73 & 9.56 & 16.79 & 29.97 & 10.68 & 71.45 & 169.41 & 56.51 & 360.61 & 233.78 & 174.38 \\
\hline Total & 83 & 76 & 75 & 94 & 176 & 77 & 281 & 616 & 230 & 1199 & 770 & 557 \\
\hline \multicolumn{13}{|l|}{$\mathrm{Cd}\left(\mathrm{mg} \cdot \mathrm{kg}^{-1}\right)$} \\
\hline $\mathrm{CaCl}_{2}$ & 0.04 & 0.05 & 0.05 & 0.03 & 0.04 & 0.28 & 0.31 & 0.24 & 0.25 & 0.55 & 0.30 & 0.19 \\
\hline DTPA & 0.22 & 0.21 & 0.21 & 0.35 & 0.69 & 0.57 & 1.63 & 1.13 & 1.41 & 1.73 & 1.15 & 0.99 \\
\hline EDTA & 0.23 & 0.24 & 0.24 & 0.50 & 0.99 & 0.78 & 1.92 & 1.79 & 1.65 & 2.32 & 1.45 & 1.25 \\
\hline Total & 1.29 & 1.52 & 1.14 & 2.54 & 4.17 & 3.16 & 5.82 & 7.26 & 5.29 & 7.15 & 4.79 & 4.11 \\
\hline \multicolumn{13}{|l|}{$\mathrm{Cr}\left(\mathrm{mg} \cdot \mathrm{kg}^{-1}\right)$} \\
\hline $\mathrm{CaCl}_{2}$ & N.D. & N.D. & N.D. & N.D. & N.D. & N.D. & N.D. & N.D. & N.D. & N.D. & N.D. & N.D. \\
\hline DTPA & N.D. & N.D. & N.D. & N.D. & N.D. & N.D. & N.D. & N.D. & N.D. & N.D. & N.D. & N.D. \\
\hline EDTA & N.D. & N.D. & N.D. & N.D. & N.D. & N.D. & N.D. & N.D. & N.D. & N.D. & N.D. & N.D. \\
\hline Total & 96 & 115 & 115 & 108 & 154 & 116 & 67 & 63 & 75 & 44 & 73 & 87 \\
\hline
\end{tabular}

Note: values presented in the table are the arithmetic mean of three replicates. N.D.: not detected.

2.4. Microbial Biomass Carbon. The amount of microbial biomass carbon (biomass $\mathrm{C}$ ) in the soil was measured by a modified fumigation extraction (FE) method [29]. Soil samples were divided into two parts: one part was fumigated with ethanol-free chloroform for $24 \mathrm{~h}$ at $25^{\circ} \mathrm{C}$ in the dark, and the second part was stored in the dark for $24 \mathrm{~h}$ at $25^{\circ} \mathrm{C}$ but not fumigated. The organic carbon was extracted from both soils using $0.5 \mathrm{M} \mathrm{K}_{2} \mathrm{SO}_{4}$ (soil : solution, $1: 4$ ). Soil extractions were shaken at $150 \mathrm{rpm}$ for $30 \mathrm{~min}$ and filtered, and then the total organic carbon was determined using a TOC analyzer (TOC102A, Analytik Jena). The microbial biomass carbon (MBC) was calculated using the following equation:

$$
\begin{aligned}
\text { MBC }= & {[\text { TOC }(\text { fumigated soil })} \\
& - \text { TOC }(\text { nonfumigated soil })] \times 2.22 .
\end{aligned}
$$

The microbial biomass was expressed as milligrams of biomass $\mathrm{C}$ per kilogram of soil.

2.5. Soil Protein Extraction. The citrate-SDS sequential extraction method $[15,16]$ was used to extract the soil proteins. Specifically, $3.0 \mathrm{~g}$ of dried soil was mixed with $15 \mathrm{~mL}$ of $0.25 \mathrm{M}$ citrate buffer ( $\mathrm{pH} 8.0$ ), and the homogenate was shaken at $1,200 \mathrm{rpm}$ in room temperature for $4 \mathrm{~h}$. Then, the suspension was centrifuged for $15 \mathrm{~min}$ at $15,000 \times \mathrm{g}$ and $4^{\circ} \mathrm{C}$ and filtered through filter paper (approximately 30 to $50 \mu \mathrm{m})$. Next, the soil was extracted using $15 \mathrm{~mL}$ of SDS buffer, which contained $1.25 \%$ (w/v) SDS, $0.1 \mathrm{M}$ Tris- $\mathrm{HCl}(\mathrm{pH}$ 6.8 ), and $20 \mathrm{mM}$ dithiothreitol (DTT). This SDS soil mixture was shaken for $1 \mathrm{~h}$ at $1,200 \mathrm{rpm}$ and room temperature, and then it was centrifuged for $15 \mathrm{~min}$ at $15,000 \times \mathrm{g}$ and $4^{\circ} \mathrm{C}$. For protein recovery, both the citrate extract and the SDS extract were mixed with buffered phenol $(\mathrm{pH} \mathrm{8.0)}$ at a volume ratio (extract:phenol) of $3: 1$ and centrifuged at $15,000 \times \mathrm{g}$ and $4^{\circ} \mathrm{C}$ for $30 \mathrm{~min}$. After centrifugation, the phenol phase was precipitated at $-20^{\circ} \mathrm{C}$ overnight with five volumes of cold $0.1 \mathrm{M}$ ammonium acetate dissolved in methanol. The proteins were recovered by centrifugation at $20,000 \times \mathrm{g}$ and $4^{\circ} \mathrm{C}$ for $20 \mathrm{~min}$. The pellets were washed once with cold methanol and twice with cold acetone, and then they were air-dried for further use.

2.6. Protein Content Determination and Protein Separation. Protein pellets were solubilized in $500 \mu \mathrm{L}$ of lysis buffer, which contained $9 \mathrm{M}$ urea, $4 \% \mathrm{w} / \mathrm{v}$ CHAPS, $1 \% \mathrm{w} / \mathrm{v}$ DTT, $0.5 \%$ ampholyte, and $1 \mathrm{mM}$ PMSF. The concentration of protein in the supernatant was determined by the Bradford method [30], and the protein was stored at $-70^{\circ} \mathrm{C}$. 
Samples of the extracted proteins were added to an equal volume of loading buffer, which contained $100 \mathrm{mM}$ Tris$\mathrm{HCl}(\mathrm{pH}$ 6.8), 4\% (w/v) SDS, 20\% glycerol, 0.5\% (w/v) bromophenol blue, and $100 \mathrm{mM}$ DTT, and then they were heated in water at $95^{\circ} \mathrm{C}$ for $5 \mathrm{~min}$ prior to SDS-PAGE [8]. Subsequently, discontinuous SDS-PAGE was performed using the Mini-PROTEAN 3 Electrophoresis Cell (Bio-Rad) with a $4 \%$ stacking gel and a $12 \%$ separating gel. The process was run at a constant $75 \mathrm{~V} /$ gel through the stacking gel and a constant $150 \mathrm{~V} /$ gel through the separating gel. A prestained protein ladder (approximately 10 to $170 \mathrm{kDa}$, Fermentas) was loaded as a molecular weight marker, and each lane was loaded with the same quantity of protein. After separation, the gels were stained by silver staining [31] for further comparisons.

2.7. DNA Extraction. The extraction of the total soil DNA was accomplished using a Sangon DNA isolation kit, according to the manufacturer's protocol (SK8233).

2.8. PCR-DGGE Microbial Community Analysis. The primers F357 and R518, 5' -CCT ACG GGA GGC AGC AGC-3' and $5^{\prime}$-ATT ACC GCG GCT GCT GG-3' [20], respectively, were used in this study for the amplification of bacterial 16S rDNA genes. The primers Com $2 x f$ and Ac1186r- $(\mathrm{pH}), 5^{\prime}$-AAA CTC AAA GGA ATT GAC GG- $3^{\prime}$ and $5^{\prime}$-CTT CCT CCG AGT TGA CCC-3' [32], respectively, were used for the amplification of actinomycete $16 \mathrm{~S}$ rDNA genes. A GC clamp (CGC CCG CCG CGC CCC GCG CCC GGC CCG CCG CCC CCG CCC C) was added to the forward primers to facilitate the DGGE [20]. The PCR reaction mixture (Takara) contained $5 \mu \mathrm{L}$ of $10 \mathrm{x}$ reaction buffer $(0.1 \mathrm{M}$ Tris- $\mathrm{HCl}$ at $\mathrm{pH} 8.3$ and $0.5 \mathrm{M}$ $\mathrm{KCl}), 6 \mu \mathrm{L}$ of $\mathrm{MgCl}_{2}(25 \mu \mathrm{M}), 1 \mu \mathrm{L}$ of each primer $(20 \mu \mathrm{M})$, $4 \mu \mathrm{L}$ of each dNTP $(2.5 \mathrm{mM}), 0.5 \mu \mathrm{L}$ of Taq DNA polymerase $\left(5 \mathrm{U} \cdot \mu \mathrm{L}^{-1}\right)$, and $2 \mu \mathrm{L}$ of DNA; milli-Q water was added to reach a total reaction volume of $50 \mu \mathrm{L}$. The PCR protocol used to amplify the soil bacterial and actinomycete $16 \mathrm{~S}$ rDNA gene fragments was as follows: a $5 \mathrm{~min}$ initial denaturation step at $94^{\circ} \mathrm{C}$, followed by 20 cycles of $94^{\circ} \mathrm{C}$ for $1 \mathrm{~min}, 65^{\circ} \mathrm{C}$ for $1 \mathrm{~min}$, and $72^{\circ} \mathrm{C}$ for $1 \mathrm{~min}$, then, 10 cycles of $94^{\circ} \mathrm{C}$ for $1 \mathrm{~min}, 55^{\circ} \mathrm{C}$ for $1 \mathrm{~min}$, and $72^{\circ} \mathrm{C}$ for $1 \mathrm{~min}$, with a final extension at $72^{\circ} \mathrm{C}$ for $7 \mathrm{~min}$ (S1000 Thermal Cycler, Bio-Rad). Prior to DGGE, the PCR products were checked by electrophoresis in $1.0 \%(\mathrm{w} / \mathrm{v})$ agarose gels stained with ethidium bromide.

For the DGGE analysis, the PCR products generated from each sample were separated on an $8 \%$ acrylamide gel using the Bio-Rad Dcode System with a linear denaturant gradient range from $30 \%$ to $60 \%$. DGGE was performed in $1 \mathrm{x}$ TAE buffer at $60^{\circ} \mathrm{C}$ and $150 \mathrm{~V}$ for $8 \mathrm{~h}$. Gels were stained with SYBRGreen I, and the gels were scanned (Bio-Rad).

2.9. Analysis of DGGE Profiles. The digitized DGGE images were analyzed by Quantity One image analysis software (Version 4.62, Bio-Rad). The Shannon index $(H)$ was used to estimate the soil microbial diversity based on the intensity and number of bands using the following equation:

$$
\text { Shannon index }(H)=-\sum \frac{n_{i}}{N} \ln \frac{n_{i}}{N} \text {, }
$$

where $i$ is the number of bands in each lane of the DGGE gel, $n_{i}$ is the peak height of band $i$, and $N$ is the sum of the peak heights in a given lane of the DGGE gel [33].

Principal component analysis (PCA) was performed by SPSS 16.0 [34], and WPGAMA cluster analysis was performed by Quantity One 4.62 to calculate the similarities of the gel patterns.

2.10. Data Analysis. All measurements of soil $\mathrm{pH}$, enzyme activity, and levels of organic matter, heavy metals, microbial biomass carbon, and proteins were performed in triplicate. All of the values reported are the average of three determinations. All of the statistical analyses were performed using SPSS software version 16.0. One-way analysis of variance (ANOVA) was used for statistical comparisons, and the Pearson coefficient was used for correlation analysis. A value of $P<0.05$ was considered statistically significant.

\section{Results}

3.1. Soil Properties. Selected soil physicochemical properties, the total heavy metal contents, and the bioavailable fraction of heavy metals are shown in Table 1 . Compared with the contaminated area, soil samples from the reference site were mildly more acidic, with a $\mathrm{pH}$ range from 5.72 to 5.94 , and had a lower organic matter content between $4.69 \%$ and $5.36 \%$. In the field contaminated by heavy metals, the soil $\mathrm{pH}$ varied from 6.23 to 8.00 , and the range of soil organic matter was from $3.23 \%$ to $7.65 \%$. The amount of organic matter in each sample was lower the further the sample was from the smelter.

In all of the soil samples, the $\mathrm{Cr}$ concentration was either below or only slightly above the natural background concentration of $90 \mathrm{mg} \cdot \mathrm{kg}^{-1}$, as defined by the Chinese Environmental Quality Standards for Soil. In addition, the bioavailable $\mathrm{Cr}$ fraction was not detected by the apparatus. Therefore, the effects of $\mathrm{Cr}$ stress on soil microorganisms were not considered.

The soils varied greatly in their concentrations of total $\mathrm{Cu}$ (approximately 175 to $1,147 \mathrm{mg} \cdot \mathrm{kg}^{-1}$ ), $\mathrm{Zn}$ (approximately 187 to $2,472 \mathrm{mg} \cdot \mathrm{kg}^{-1}$ ), $\mathrm{Pb}$ (approximately 77 to $1,199 \mathrm{mg} \cdot \mathrm{kg}^{-1}$ ), and $\mathrm{Cd}$ (approximately 2.54 to $7.26 \mathrm{mg} \cdot \mathrm{kg}^{-1}$ ) with their distances from the smelter. The highest concentrations of $\mathrm{Cu}$, $\mathrm{Zn}$, and $\mathrm{Pb}$ were found in the samples nearest to smelter $(200 \mathrm{~m})$, but the highest Cd level was found in the sample $400 \mathrm{~m}$ away (Table 1).

3.2. Concentration of Bioavailable Heavy Metals. The fraction of metal, that is, in its bioavailable form, is crucial to understanding metal ecological toxicity. The bioavailability of heavy metals is related to their chemical forms in soil. Several fractions or compartments of the soil act as reservoirs for bioavailable metals [3]. Extractions by $\mathrm{CaCl}_{2}, \mathrm{DTPA}$, and EDTA are widely used methods of soil analysis, providing an operationally defined soil compartment that is characterized by its mobility and bioavailability. $\mathrm{CaCl}_{2}$ is used to estimate the soluble and exchangeable metals. DTPA and EDTA are predominantly used to study the metals that have bonded 


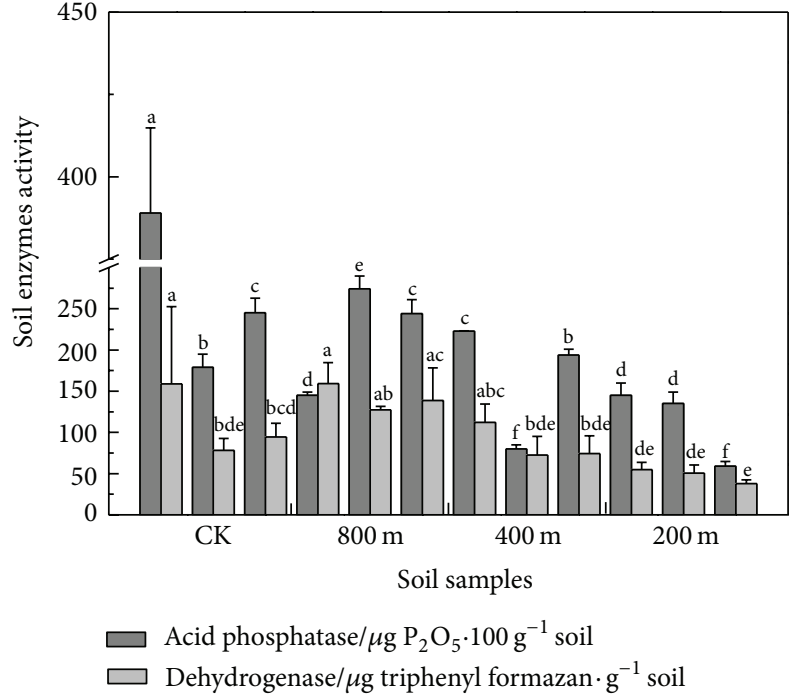

FIGURE 1: The effect of heavy metals on the activities of soil enzymes. Note: different letters in same enzyme indicate significant differences $(P<0.05)$.

with organic matter and the overall phytoavailability of heavy metals $[18,19]$.

The concentrations of bioavailable $\mathrm{Cu}, \mathrm{Zn}, \mathrm{Pb}$, and $\mathrm{Cd}$ in the soil samples varied significantly (Table 1 ). The amount of bioavailable heavy metals in the soil decreased with increasing distance from the smelter, and the bioavailable fractions of heavy metals were significantly positively correlated with the total heavy metals $(P<0.05)$. In all of the soil samples, the concentration of $\mathrm{CaCl}_{2}$-extractable metals $<$ DTPAextractable metals < EDTA-extractable metals. These results correlated with the extraction abilities of the reagents [35]. The concentration of $\mathrm{CaCl}_{2}$-extractable heavy metals was far less than those of the DTPA- and EDTA-extractable heavy metals. This result indicates that heavy metals bonded with organic matter and were predominantly in their bioavailable form, agreeing with the conclusion that heavy metals in soil are primarily associated with soil organic matter $[36,37]$. It is this bioavailable fraction of heavy metals that greatly affects soil microorganisms [1].

3.3. Soil Enzyme Activities. The variations in the activities of acid phosphatase and dehydrogenase in the soil samples are shown in Figure 1. Good correlations were observed between enzyme activity and distance from the smelter. Compared with the reference area (CK), acid phosphatase activity was inhibited in the sites contaminated by heavy metals. Soil acid phosphatase activity tended to decrease with increasing heavy metals. A significant decrease was observed in the samples only $200 \mathrm{~m}$ away from the smelter. Conversely, dehydrogenase activity was slightly increased in the soil samples $800 \mathrm{~m}$ away from the smelter and decreased as the distance from the smelter decreased. This result indicates that a low level of heavy metals will stimulate soil microbes to synthesize dehydrogenase, promoting microbial metabolic activity.
TABLE 2: The Pearson correlation coefficients between the microbial parameters and the concentrations of heavy metals.

\begin{tabular}{|c|c|c|c|c|}
\hline & $\begin{array}{c}\text { Acid } \\
\text { phosphatase }\end{array}$ & Dehydrogenase & $\begin{array}{l}\text { Microbial } \\
\text { biomass C }\end{array}$ & Protein \\
\hline \multicolumn{5}{|l|}{$\mathrm{Cu}$} \\
\hline $\mathrm{CaCl}_{2}$ & -0.500 & $-0.597^{*}$ & $-0.632^{*}$ & $-0.705^{*}$ \\
\hline EDTA & $-0.576^{*}$ & $-0.628^{*}$ & $-0.834^{* *}$ & $-0.884^{* *}$ \\
\hline DTPA & -0.568 & $-0.649^{*}$ & $-0.839^{* *}$ & $-0.874^{* *}$ \\
\hline Total & $-0.586^{*}$ & $-0.594^{*}$ & $-0.729^{* *}$ & $-0.866^{* *}$ \\
\hline \multicolumn{5}{|l|}{$\mathrm{Zn}$} \\
\hline $\mathrm{CaCl}_{2}$ & -0.400 & $-0.584^{*}$ & $-0.604^{*}$ & -0.543 \\
\hline EDTA & -0.554 & $-0.685^{*}$ & $-0.683^{*}$ & $-0.596^{*}$ \\
\hline DTPA & $-0.613^{*}$ & $-0.734^{* *}$ & $-0.748^{* *}$ & $-0.698^{*}$ \\
\hline Total & -0.531 & $-0.680^{*}$ & $-0.716^{* *}$ & $-0.653^{*}$ \\
\hline \multicolumn{5}{|l|}{$\mathrm{Pb}$} \\
\hline $\mathrm{CaCl}_{2}$ & -0.239 & -0.485 & -0.303 & -0.219 \\
\hline EDTA & $-0.586^{*}$ & $-0.709^{* *}$ & $-0.624^{*}$ & $-0.643^{*}$ \\
\hline DTPA & $-0.719^{* *}$ & $-0.760^{* *}$ & $-0.583^{*}$ & $-0.669^{*}$ \\
\hline Total & -0.569 & $-0.693^{*}$ & $-0.604^{*}$ & $-0.645^{*}$ \\
\hline \multicolumn{5}{|l|}{$\mathrm{Cd}$} \\
\hline $\mathrm{CaCl}_{2}$ & -0.379 & -0.515 & -0.551 & -0.542 \\
\hline EDTA & -0.486 & -0.544 & $-0.679^{*}$ & $-0.814^{* *}$ \\
\hline DTPA & -0.425 & -0.539 & $-0.726^{* *}$ & $-0.794^{* *}$ \\
\hline Total & -0.528 & -0.494 & $-0.576^{*}$ & $-0.817^{* *}$ \\
\hline
\end{tabular}

Note: ${ }^{* *}$ correlation is significant at the 0.01 level (2-tailed).

${ }^{*}$ Correlation is significant at the 0.05 level (2-tailed).

Soil acid phosphatase activity was significantly negatively correlated with EDTA-extractable $\mathrm{Cu}$ and Pb; DTPAextractable $\mathrm{Zn}$ and $\mathrm{Pb}$; and total $\mathrm{Cu}$. Similarly, dehydrogenase activity was significantly negatively correlated with $\mathrm{CaCl}_{2}$ extractable $\mathrm{Cu}$ and $\mathrm{Zn}$; EDTA-extractable $\mathrm{Cu}, \mathrm{Zn}$, and $\mathrm{Pb}$; DTPA-extractable $\mathrm{Cu}, \mathrm{Zn}$, and $\mathrm{Pb}$; and total $\mathrm{Cu}, \mathrm{Zn}$, and $\mathrm{Pb}$ (Table 2).

3.4. Microbial Biomass Carbon in Soil. The amount of microbial biomass carbon (MBC) in the contaminated soil samples ranged from 44.6 to $105.0 \mathrm{mg} \cdot \mathrm{kg}^{-1}$, as measured by the $\mathrm{FE}$ method, which are lower values than those of the reference site (Figure 2). A significant decrease was observed in the soil samples only $200 \mathrm{~m}$ away from the smelter, with the $\mathrm{MBC}$ increasing from the plot nearest to the plot farthest away $(800 \mathrm{~m})$. The amount of soil MBC was significantly negatively correlated with $\mathrm{CaCl}_{2}$-extractable $\mathrm{Cu}$ and $\mathrm{Zn}$; EDTA-extractable $\mathrm{Cu}, \mathrm{Zn}, \mathrm{Pb}$, and Cd; DTPA-extractable $\mathrm{Cu}$, $\mathrm{Zn}, \mathrm{Pb}$, and $\mathrm{Cd}$; and total $\mathrm{Cu}, \mathrm{Zn}, \mathrm{Pb}$, and $\mathrm{Cd}$ (Table 2). These results indicate that the concentrations of DTPA- and EDTA-extractable heavy metals are better predictors of the effects that heavy metals have on MBC compared with the concentrations of $\mathrm{CaCl}_{2}$-extractable heavy metals.

3.5. Soil Microorganism Community Composition. The idea of using a DGGE analysis of soil microbial communities to 


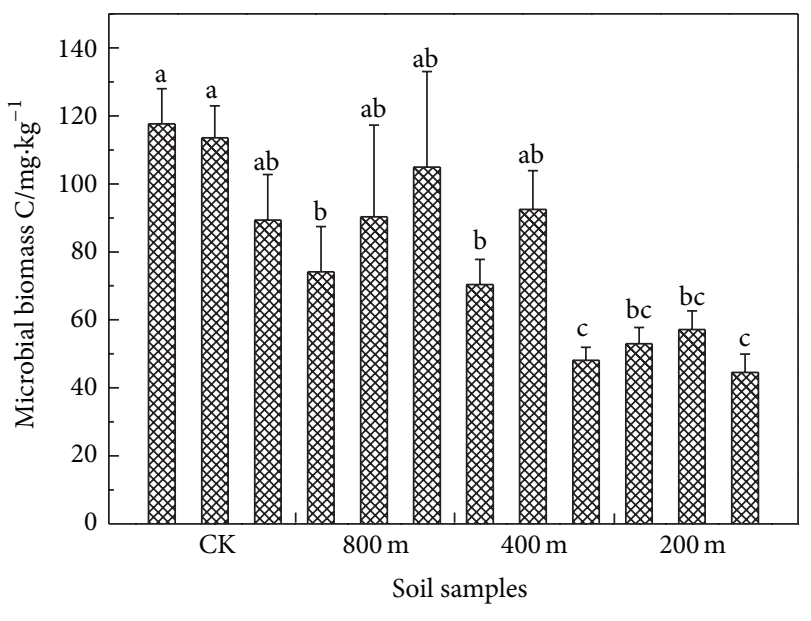

Microbial biomass C

FIgURE 2: The effect of heavy metals on the microbial biomass carbon in soil. Note: the different letters indicate significant differences $(P<0.05)$.

investigate soil microbial diversity was first introduced by Muyzer et al. (1993). DGGE proved to be capable of accurately measuring soil microbial diversity, so it has become the predominant technique in soil microbial ecology for profiling soil microbial communities and monitoring shifts in microbial community composition due to environmental changes [38]. The DGGE profiles of the soil bacteria and actinomycetes are shown in Figures 3(a) and 4(a). Although many bands were found in all lanes, obvious differences in the intensities of the soil microbial communities were clearly observed (Figures 3(a) and 4(a)). As shown in Figure 3(a), the number of bands in the soil was significantly increased with an increasing distance from the smelter; in other words, the number of bands in the DGGE profile increased as the heavy metals presence decreased. A similar result was also found in the soil actinomycete community composition. Compared with the soils from the reference site and from $800 \mathrm{~m}$ away, the number of bands in the plots situated at $400 \mathrm{~m}$ and $200 \mathrm{~m}$ were significantly decreased (Figure 4(a)).

Subsequently, the DGGE gels were interpreted by the Shannon index, principal component analysis (PCA), and cluster analysis to examine the number, presence, and relative intensity of the bands. The Shannon index indicated that the diversity of the soil microorganisms (bacteria and actinomycetes) was decreased significantly with an increase in the heavy metals concentration (Table 3). PCA and the cluster analysis are also useful methods for analyzing DGGE profiles. The PCA plots show a clear separation due to the different distances from the smelter, demonstrating the altered structure and diversity of the microbial community. Using the presence of the bands as input data, the first two principal components (PC1 and PC2) were sufficient to explain $79.5 \%$ and $78.0 \%$ of the variance in the soil bacteria and the actinomycetes, respectively (Figures 3(b) and 4(b)). The similarity between the soil bacterial and actinomycete communities of the reference site and those of the soil taken around the smelter was obtained from a cluster analysis of the DGGE profile and was determined to be less than $50 \%$ (Figures 3(c) and 4(c)). The cluster analysis indicated that the soil microorganism community structure was greatly affected by the presence of heavy metals.

3.6. Soil Protein Expression. The amount of protein in the contaminated soil samples ranged from 15.6 to $104 \mu \mathrm{g} \cdot \mathrm{g}^{-1}$, far less than the amount found at the reference site (Figure 5(a)). The concentration of protein decreased drastically when the soil was slightly contaminated by heavy metals at a distance of $800 \mathrm{~m}$ from the smelter. The quantity of soil proteins was significantly negatively correlated with soil $\mathrm{CaCl}_{2}$-extractable $\mathrm{Cu}$; EDTA-extractable $\mathrm{Cu}, \mathrm{Zn}, \mathrm{Pb}$, and Cd; DTPA-extractable $\mathrm{Cu}, \mathrm{Zn}, \mathrm{Pb}$, and $\mathrm{Cd}$; and total $\mathrm{Cu}, \mathrm{Zn}, \mathrm{Pb}$, and $\mathrm{Cd}$ (Table 2).

The protein profiles are shown in Figure 5(b). The results indicate that no discernible differences exist between the composition and location of the citrate-extracted protein band of the reference site and those of the soil samples from $800 \mathrm{~m}$ and $400 \mathrm{~m}$. The bands from these three sample sets were almost entirely located between approximately 55 and $70 \mathrm{kD}$. However, some type of protein, that is, $40 \mathrm{kD}$ in size, was only found in the soil $200 \mathrm{~m}$ from the smelter. Additionally, although the SDS buffer extracts showed similar protein patterns between different soil samples, the expression of some proteins was significantly different. Compared with the contaminated soil samples, the uncontaminated samples had more abundant proteins overall. In the contaminated soil, with its increased concentration of heavy metals, there were fewer large molecular weight $(>35 \mathrm{kD})$ proteins and more low molecular weight proteins (approximately $15 \mathrm{kD}$ ). At the base of each contaminated profile was a large agglomeration of presumably low molecular weight proteinaceous material that produced dark areas on the gels. Therefore, these low molecular weight proteins were largely aggregated.

\section{Discussion}

The activity and community composition of soil microbes are closely related to soil fertility and environmental quality. Additionally, soil biological parameters may have potential for use as early and sensitive indicators of soil ecological stress and restoration. Currently, the amount of microbial biomass carbon and enzyme activity are the metrics predominantly used to provide information about the biochemical processes occurring in the soil $[3,39]$. The soil microbial biomass is the total mass of microorganisms living in the soil, which is the living part of the soil organic matter [1]. Soil phosphatase plays an essential role in the mineralization of organic phosphorus, while dehydrogenase is an intracellular enzyme that is involved in microbial oxidoreductase metabolism [3, 39].

In our study, the amount of microbial biomass $\mathrm{C}$ in the soil decreased when the concentration of heavy metals increased, although the difference was not significant when the heavy metals were at a low level. This finding is not surprising. Microorganisms differ in their sensitivity to metal toxicity, and the development of metal-tolerant strains, as well as shifts in the community structure, could compensate for 


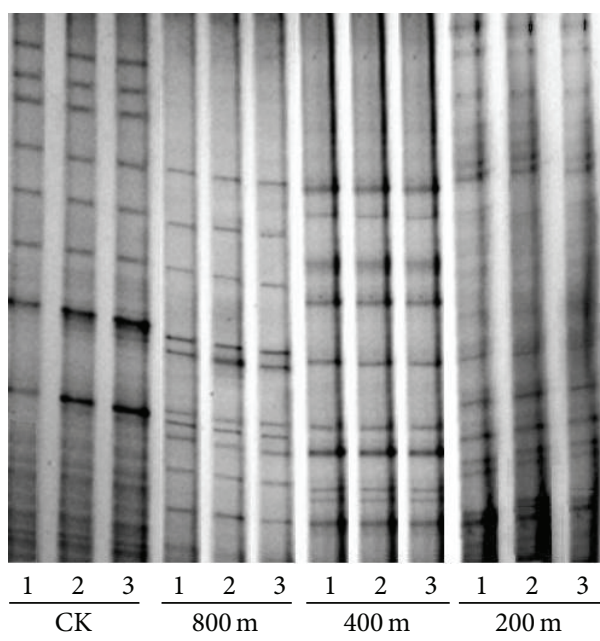

(a)

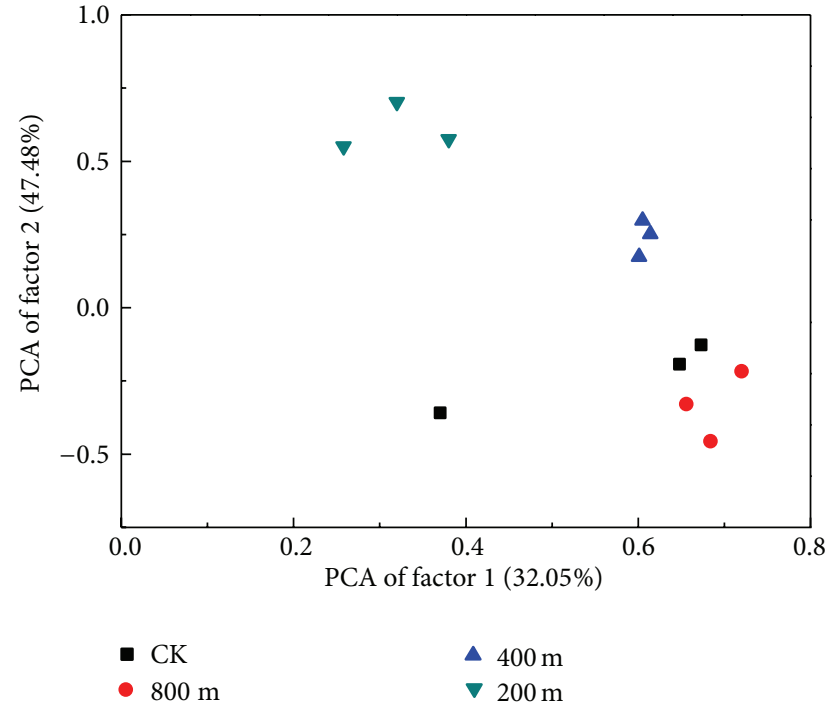

(b)

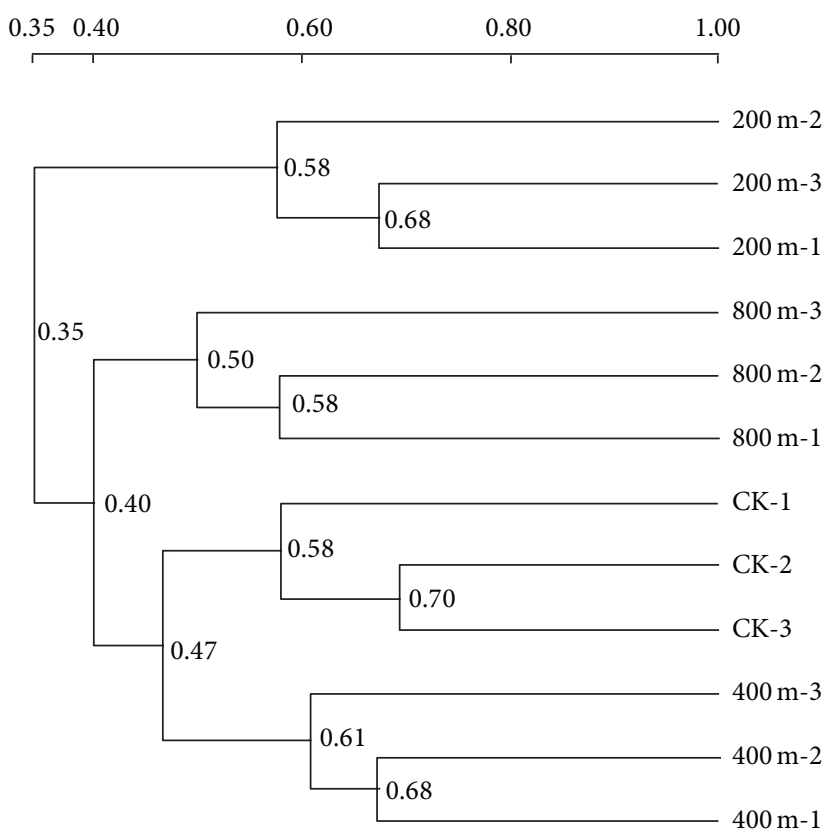

(c)

FIGURE 3: The effect of heavy metals on soil bacterial communities. (a) The DGGE profiles of the bacterial communities inhabiting each soil sample. (b) A principle component analysis based on the DGGE profiles of soil bacteria. (c) A cluster analysis based on the DGGE profiles of soil bacteria.

the loss of more sensitive populations [2]. The reduction in soil microbial biomass $\mathrm{C}$ might also explain the inhibition of enzyme activity observed in the heavy metal contaminated soil.

It is important to differentiate between extracellular and intracellular enzymes when we study the changes of enzymes under pollutant stress. The dehydrogenase activity, which is only present in viable cells and essentially depends on the metabolic state of the soil biota, may therefore be considered a direct measure of soil microbial activity. In contrast, phosphatase activity can occur extracellularly as well as within a living cell $[1,3,6,26,39]$. For example, Brookes et al. [40] reported less dehydrogenase activity in metal-contaminated soil than in similar uncontaminated soil, while the soil phosphatase was unaffected. This might explain why, in our study, the dehydrogenase activity was also more sensitive to the heavy metal stress than the acid phosphatase activity.

Furthermore, the dehydrogenase activity was significantly correlated with soil microbial biomass $\mathrm{C}(r=0.611$, $P<0.05$ ). These results suggest that microbial biomass $C$ and dehydrogenase can be useful measures of the level of heavy metal contamination in a soil sample $[26,39]$. 

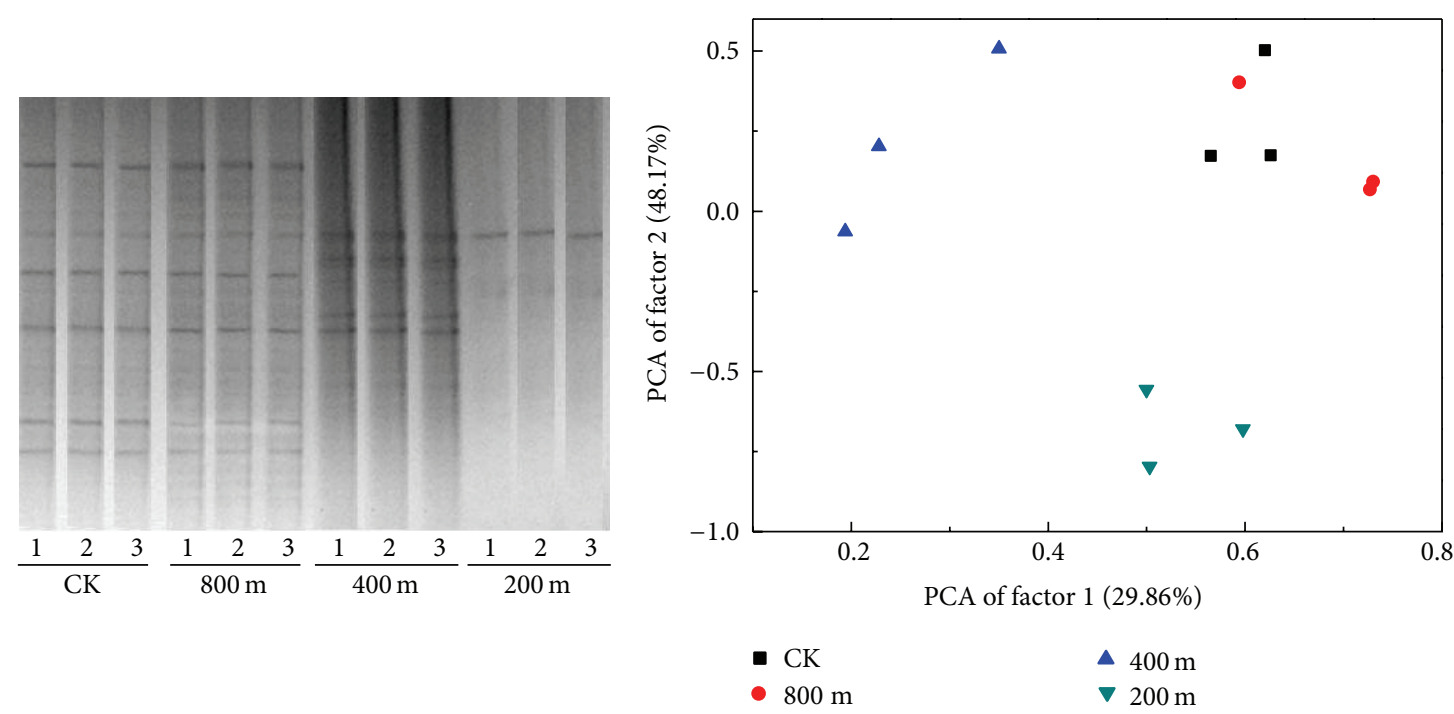

(a)

(b)

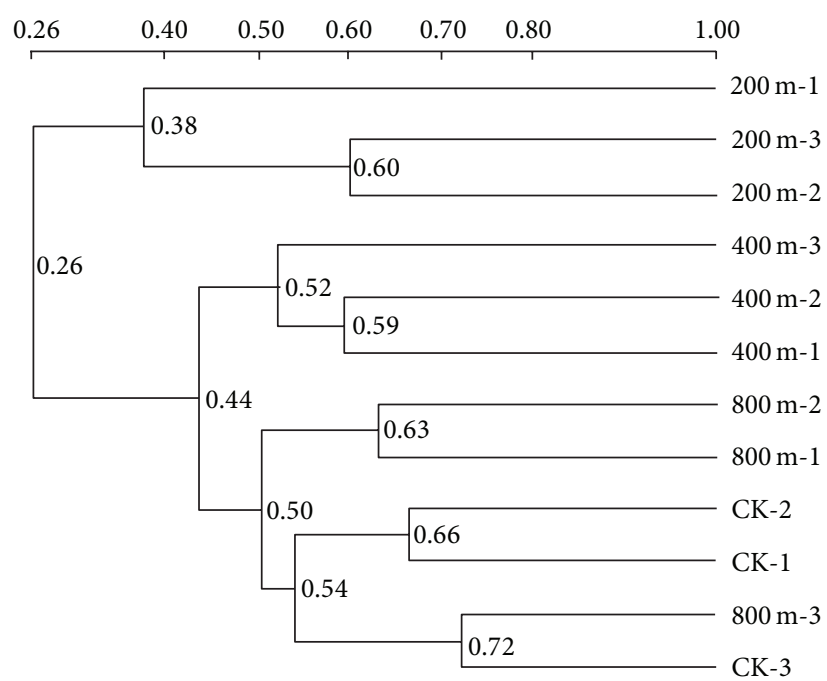

(c)

FIGURE 4: The effect of heavy metals on soil actinomycetes communities. (a) The DGGE profiles of the actinomycete communities inhabiting each soil sample. (b) A principle component analysis based on the DGGE profiles of soil actinomycetes. (c) A cluster analysis based on the DGGE profiles of soil actinomycetes.

The microbial biomass and enzyme activity measurements have their limitations in soil pollution studies, however. For example, the changes were not notable when heavy metal concentrations were low and highly soluble $\mathrm{Cu}$ generated chromogen interference to dehydrogenase activity measurements [41]. In addition, the changes in the microorganism community structure cannot be evaluated by such techniques. Therefore, the use of soil enzyme and microbial biomass as indicators for soil contaminated by heavy metals still needs further discussions.

The changes in the metabolic profiles indicate the possibility that heavy metal contamination results in a community that is more variable and less stable [3]. In our study, the genetic structure and protein expression of the indigenous soil microbial communities were evaluated by an advanced molecular technique that is based on PCRDGGE and SDS-PAGE. The PCR-DGGE method has become a predominant molecular technique to study the changes in soil microorganisms due to contamination and agricultural practices [3, 20, 42]. In contrast, the use of SDSPAGE to monitor contaminated soil is still in its infancy $[7,8,17]$. The results of the DGGE profiles, as analyzed by principal component analysis (PCA) and cluster analysis in this study, make it clear that the number and intensity of DNA bands in the different samples changed significantly. This significant difference between the samples indicates that the soil microbial community structure changed greatly in response to heavy metals contamination (Table 3, Figures 3-4). We also detected an increased relative abundance in the microbial populations with increasing distance from the 


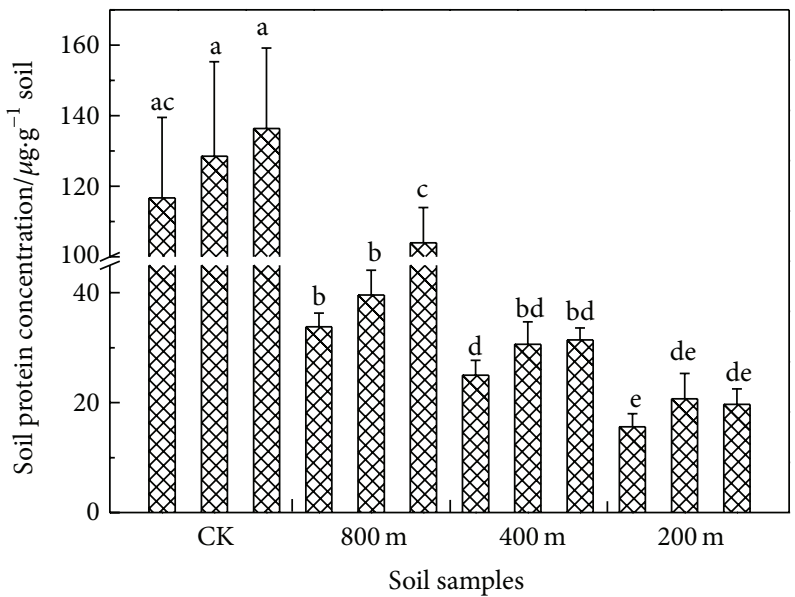

Soil protein concentration

(a)
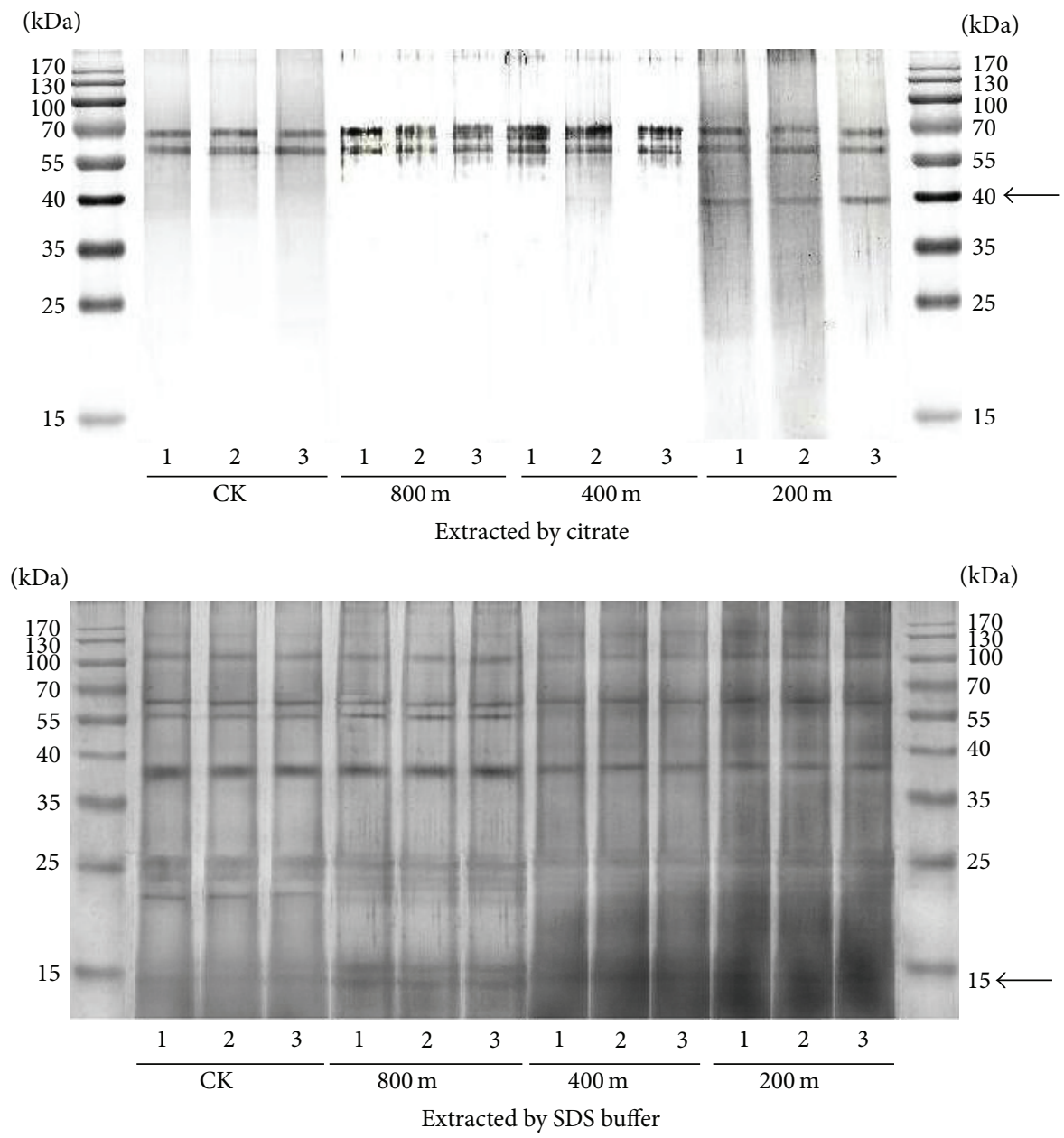

(b)

Figure 5: The effect of the concentration of heavy metals on soil protein. (a) The effect of the concentration of heavy metals on the amount of soil proteins. Note: Different letters indicate significant differences $(P<0.05)$. (b) The effect of the heavy metals concentration on soil protein expressions. 
TABLE 3: The Shannon diversity index for the soil samples contaminated by heavy metals.

\begin{tabular}{lcc}
\hline Distance & Soil bacteria & Soil actinomycetes \\
\hline CK & $3.11 \pm 0.11^{\mathrm{a}}$ & $0.52 \pm 0.02^{\mathrm{a}}$ \\
$800 \mathrm{~m}$ & $2.91 \pm 0.12^{\mathrm{b}}$ & $0.40 \pm 0.03^{\mathrm{b}}$ \\
$400 \mathrm{~m}$ & $2.90 \pm 0.07^{\mathrm{b}}$ & $0.35 \pm 0.01^{\mathrm{c}}$ \\
$200 \mathrm{~m}$ & $2.48 \pm 0.08^{\mathrm{c}}$ & $0.23 \pm 0.02^{\mathrm{d}}$ \\
\hline
\end{tabular}

Note: values presented in the table are the mean \pm standard deviation $(n=$ 3).

Values in each column followed by different letters are significantly different $(P<0.05)$.

smelter, demonstrating that heavy metals exerted a major effect on bacterial diversity by promoting changes in species composition (represented by the position of the bands) and in species richness (represented by the number of occurring bands). Namely, contamination inhibited certain bacterial groups and stimulated others, and it changed the overall microbial diversity $[2,3,38,43,44]$.

Subsequently, the content and composition of the soil proteins were studied to investigate their changes under heavy metals stress. Compared with the reference site, the soil protein levels decreased significantly due to heavy metals contamination, and the percentage decrease in total soil proteins was larger than the decrease detected in soil enzyme activity or microbial biomass carbon (Figure 5(a)). The soil protein concentrations were significantly negatively correlated with heavy metals (Table 2 ). These results indicate that proteins are more sensitive to the changes caused by pollutants, making protein concentration a great potential indicator of soil pollution. The variation in soil proteins may be due to modifications in the microbial community composition $[7,8]$. This hypothesis was confirmed by the DGGE profiles in our study (Figures 3(a) and 4(a)). Although protein has potential to be an indictor for soil contamination, its reliability still needs more studies since Bradford method is easily affected by humic substances present in protein solution [45].

The collected soil proteins were separated by SDS-PAGE, and we found that several bands were common to all soils. We also found more presumably low molecular weight proteins in the contaminated soil than in the soil of the reference site (Figure 5(b)). This protein could be related to the presence of heavy metals and could be a microbial response to the metals $[8,46]$. For example, many eukaryotic microbes are known to produce metallothioneins (a low molecular weight protein) in response to metal (particularly $\mathrm{Cd}$ ) exposure $[47,48]$. Another explanation may be that sufficient metal exposure will result in the immediate death of cells due to a disruption of their essential functions; thus, the cells are lysed, and their proteins are released into the environment, where they are quickly degraded into low molecular weight materials $[2,8]$. Obviously, more work is needed to identify this low molecular weight protein and understand its role in the microbial responses to heavy metals stress. This protein should also be investigated as an indicator for soil pollution.

Although PCR-DGGE and SDS-PAGE are useful for monitoring the changes in microbial community structures, they still have drawbacks. These approaches are easily interfered with by impurities that are coextracted with the soil
DNA and proteins, primarily humic substances $[7,38]$. The DNA and proteins that are mixed in with the organic matter are not easily separated by DGGE or SDS-PAGE. In addition, relatively small populations of microbes and low abundances of proteins may not be identified by DGGE and SDS-PAGE, respectively $[8,38]$. In this study, for example, both the DGGE and SDS-PAGE profiles have a dark background and smeared dark areas at the bottom of SDS-PAGE gel, which make the accuracy and reliability of the analysis questionable. Consequently, the molecular techniques used in this study have much room for improvement, and more work is required to develop effective extraction methods for soil DNA and proteins.

No single technique can provide a comprehensive depiction of the soil microbial situation. Therefore, soil microbial activity and diversity are difficult to elucidate. To obtain a better understanding of soil microbial ecology, we need to integrate different methods to create a comprehensive analysis.

\section{Conclusions}

By combining different monitoring techniques for different aspects of microbiology, we can obtain a better understanding of the soil microorganisms that live in soils contaminated by heavy metals. Our study demonstrated that heavy metals have a significant negative effect on the activities of soil acid phosphatase and dehydrogenase as well as on the levels of proteins and microbial biomass carbon. Compared with the other potential contamination markers tested, the protein level showed the most dramatic decrease in slightly contaminated soil, indicating that it may be more sensitive to heavy metals. Subsequently, the denaturing gradient gel electrophoresis analysis used in this study demonstrated that heavy metals had a significant negative effect on soil microbial diversity and community structure. Furthermore, the soil protein expression was similar in different soils, but a large quantity of presumably low molecular weight protein was observed only in heavy metal contaminated soil. Based on the research described in this paper, we can conclude that the soil protein level has great potential to be a sensitive indicator of soil contamination. Further research is essential to identify the low molecular weight protein that only appears in contaminated soil.

\section{Acknowledgments}

This work was financially supported by the National Natural Science Foundation of China (11179025), National Natural Science Foundation for the Youth of China (21007055), Science Foundation for Postdoctor of China (20100471714, 201104718), and Program for New Century Excellent Talents in University (NCET-11-0455).

\section{References}

[1] P. C. Brookes, "The use of microbial parameters in monitoring soil pollution by heavy metals," Biology and Fertility of Soils, vol. 19, no. 4, pp. 269-279, 1995. 
[2] K. E. Giller, E. Witter, and S. P. Mcgrath, “Toxicity of heavy metals to microorganisms and microbial processes in agricultural soils: a review," Soil Biology and Biochemistry, vol. 30, no. 10-11, pp. 1389-1414, 1998.

[3] Y. Wang, J. Shi, H. Wang, Q. Lin, X. Chen, and Y. Chen, "The influence of soil heavy metals pollution on soil microbial biomass, enzyme activity, and community composition near a copper smelter," Ecotoxicology and Environmental Safety, vol. 67, no. 1, pp. 75-81, 2007.

[4] G. Renella, M. Mench, L. Landi, and P. Nannipieri, "Microbial activity and hydrolase synthesis in long-term Cd-contaminated soils," Soil Biology and Biochemistry, vol. 37, no. 1, pp. 133-139, 2005.

[5] A. K. Müller, K. Westergaard, S. Christensen, and S. J. Sørensen, "The effect of long-term mercury pollution on the soil microbial community," FEMS Microbiology Ecology, vol. 36, no. 1, pp. 1119, 2001.

[6] C. Trasar-Cepeda, M. C. Leirós, S. Seoane, and F. Gil-Sotres, "Limitations of soil enzymes as indicators of soil pollution," Soil Biology and Biochemistry, vol. 32, no. 13, pp. 1867-1875, 2000.

[7] F. Bastida, J. L. Moreno, C. Nicolás, T. Hernández, and C. García, "Soil metaproteomics: a review of an emerging environmental science. Significance, methodology and perspectives," European Journal of Soil Science, vol. 60, no. 6, pp. 845-859, 2009.

[8] I. Singleton, G. Merrington, S. Colvan, and J. S. Delahunty, “The potential of soil protein-based methods to indicate metal contamination," Applied Soil Ecology, vol. 23, no. 1, pp. 25-32, 2003.

[9] P.-A. Maron, L. Ranjard, C. Mougel, and P. Lemanceau, "Metaproteomics: a new approach for studying functional microbial ecology," Microbial Ecology, vol. 53, no. 3, pp. 486-493, 2007.

[10] P. Wilmes and P. L. Bond, "The application of two-dimensional polyacrylamide gel electrophoresis and downstream analyses to a mixed community of prokaryotic microorganisms," Environmental Microbiology, vol. 6, no. 9, pp. 911-920, 2004.

[11] P. Wilmes and P. L. Bond, "Metaproteomics: studying functional gene expression in microbial ecosystems," Trends in Microbiology, vol. 14, no. 2, pp. 92-97, 2006.

[12] S. Criquet, A. M. Farnet, and E. Ferre, "Protein measurement in forest litter," Biology and Fertility of Soils, vol. 35, no. 5, pp. 307-313, 2002.

[13] W. X. Schulze, G. Gleixner, K. Kaiser, G. Guggenberger, M. Mann, and E.-D. Schulze, "A proteomic fingerprint of dissolved organic carbon and of soil particles," Oecologia, vol. 142, no. 3, pp. 335-343, 2005.

[14] E. B. Taylor and M. A. Williams, "Microbial protein in soil: influence of extraction method and $\mathrm{C}$ amendment on extraction and recovery," Microbial Ecology, vol. 59, no. 2, pp. 390-399, 2010.

[15] S. Chen, M. C. Rillig, and W. Wang, "Improving soil protein extraction for metaproteome analysis and glomalin-related soil protein detection," Proteomics, vol. 9, no. 21, pp. 4970-4973, 2009.

[16] H.-B. Wang, Z.-X. Zhang, H. Li et al., "Characterization of metaproteomics in crop rhizospheric soil," Journal of Proteome Research, vol. 10, no. 3, pp. 932-940, 2011.

[17] D. Benndorf, G. U. Balcke, H. Harms, and M. Von Bergen, "Functional metaproteome analysis of protein extracts from contaminated soil and groundwater," ISME Journal, vol. 1, no. 3, pp. 224-234, 2007.

[18] L. A. Brun, J. Maillet, P. Hinsinger, and M. Pépin, "Evaluation of copper availability to plants in copper-contaminated vineyard soils," Environmental Pollution, vol. 111, no. 2, pp. 293-302, 2001.
[19] E. Meers, R. Samson, F. M. G. Tack et al., "Phytoavailability assessment of heavy metals in soils by single extractions and accumulation by Phaseolus vulgaris," Environmental and Experimental Botany, vol. 60, no. 3, pp. 385-396, 2007.

[20] G. Muyzer, E. C. de Waal, and A. G. Uitterlinden, "Profiling of complex microbial populations by denaturing gradient gel electrophoresis analysis of polymerase chain reaction-amplified genes coding for 16S rRNA," Applied and Environmental Microbiology, vol. 59, no. 3, pp. 695-700, 1993.

[21] E. Baath, A. Frostegaard, T. Pennanen, and H. Fritze, "Microbial community structure and $\mathrm{pH}$ response in relation to soil organic matter quality in wood-ash fertilized, clear-cut or burned coniferous forest soils," Soil Biology and Biochemistry, vol. 27, no. 2, pp. 229-240, 1995.

[22] X. Tang, C. Shen, D. Shi et al., "Heavy metal and persistent organic compound contamination in soil from Wenling: an emerging e-waste recycling city in Taizhou area, China," Journal of Hazardous Materials, vol. 173, no. 1-3, pp. 653-660, 2010.

[23] E. Lakanen and R. Ervio, "A comparison of eight extractants for determination of plant available micronutrients in soil," Acta Agraria Fennica, vol. 123, pp. 223-232, 1971.

[24] W. L. Lindsay and W. A. Norvell, "Development of a DTPA soil test for zinc, iron, manganese, and copper," Soil Science Society of America Journal, vol. 42, pp. 421-428, 1978.

[25] P. Quevauviller, "Operationally defined extraction procedures for soil and sediment analysis I. Standardization," Trends in Analytical Chemistry, vol. 17, no. 5, pp. 289-298, 1998.

[26] C. Garcia, T. Hernandez, F. Costa, and B. Ceccanti, "Biochemical parameters in soils regenerated by the addition of organic wastes," Waste Management and Research, vol. 12, no. 6, pp. 457466, 1994.

[27] S. Y. Guan, Soil Enzyme and Its Research Methods, Agricultural Press, Beijing, China, 1986.

[28] X. Lin, Principles and Methods of Soil Microbiology Research, Higher Education Press, Beijing, China, 2010.

[29] E. D. Vance, P. C. Brookes, and D. S. Jenkinson, "An extraction method for measuring soil microbial biomass C," Soil Biology and Biochemistry, vol. 19, no. 6, pp. 703-707, 1987.

[30] M. M. Bradford, "A rapid and sensitive method for the quantitation of microgram quantities of protein utilizing the principle of protein dye binding," Analytical Biochemistry, vol. 72, no. 1-2, pp. 248-254, 1976.

[31] J. X. Yan, R. Wait, T. Berkelman et al., "A modified silver staining protocol for visualization of proteins compatible with matrix-assisted laser desorption/ionization and electrospray ionization- mass spectrometry," Electrophoresis, vol. 21, pp. 3666-3672, 2000.

[32] J. Schäfer, U. Jäckel, and P. Kämpfer, "Development of a new PCR primer system for selective amplification of Actinobacteria," FEMS Microbiology Letters, vol. 311, pp. 103-112, 2010.

[33] G. W. Yeates, H. J. Percival, and A. Parshotam, "Soil nematode responses to year-to-year variation of low levels of heavy metals," Australian Journal of Soil Research, vol. 41, no. 3, pp. 613-625, 2003.

[34] C. D. Clegg, R. D. L. Lovell, and P. J. Hobbs, "The impact of grassland management regime on the community structure of selected bacterial groups in soils," FEMS Microbiology Ecology, vol. 43, no. 2, pp. 263-270, 2003.

[35] C. R. M. Rao, A. Sahuquillo, and J. F. Lopez Sanchez, "A review of the different methods applied in environmental geochemistry for single and sequential extraction of trace elements in soils 
and related materials," Water, Air, and Soil Pollution, vol. 189, no. 1-4, pp. 291-333, 2008.

[36] A. Manceau, M.-C. Boisset, G. Sarret et al., "Direct determination of lead speciation in contaminated soils by EXAFS spectroscopy," Environmental Science and Technology, vol. 30, no. 5, pp. 1540-1552, 1996.

[37] D. G. Strawn and L. L. Baker, "Molecular characterization of copper in soils using X-ray absorption spectroscopy," Environmental Pollution, vol. 157, no. 10, pp. 2813-2821, 2009.

[38] J. Zhou, X. Sun, J. Jiao, M. Liu, F. Hu, and H. Li, "Dynamic changes of bacterial community under the influence of bacterial-feeding nematodes grazing in prometryne contaminated soil," Applied Soil Ecology, vol. 64, pp. 70-76, 2013.

[39] J. C. García-Gil, C. Plaza, P. Soler-Rovira, and A. Polo, "Longterm effects of municipal solid waste compost application on soil enzyme activities and microbial biomass," Soil Biology and Biochemistry, vol. 32, no. 13, pp. 1907-1913, 2000.

[40] P. Brookes, S. McGrath, D. Klein, and E. Elliott, "Effects of heavy metals on microbial activity and biomass in field soils treated with sewage sludge," in Environmental Contamination, pp. 574583, CEP Consultants, Edinburgh, Scotland, 1984.

[41] K. Chander and P. C. Brookes, "Is the dehydrogenase assay invalid as a method to estimate microbial activity in coppercontaminated soils?" Soil Biology and Biochemistry, vol. 23, no. 10, pp. 909-915, 1991.

[42] M. Cea, M. Jorquera, O. Rubilar, H. Langer, G. Tortella, and M. C. Diez, "Bioremediation of soil contaminated with pentachlorophenol by Anthracophyllum discolor and its effect on soil microbial community," Journal of Hazardous Materials, vol. 181, no. 1-3, pp. 315-323, 2010.

[43] K. Arnebrant, E. Bååth, and A. Nordgren, "Copper tolerance of microfungi isolated from polluted and unpolluted forest soil," Mycologia, vol. 79, no. 6, pp. 890-895, 1987.

[44] E. Baath, "Effects of heavy metals in soil on microbial processes and populations (a review)," Water, Air, and Soil Pollution, vol. 47, no. 3-4, pp. 335-379, 1989.

[45] P. Roberts and D. L. Jones, "Critical evaluation of methods for determining total protein in soil solution," Soil Biology and Biochemistry, vol. 40, no. 6, pp. 1485-1495, 2008.

[46] M. Hodson, "Effects of heavy metals and metalloids on soil organisms," in Heavy Metals in Soils, B. J. Alloway, Ed., pp. 141160, Springer, Amsterdam, The Netherlands, 2013.

[47] C. A. Blindauer, "Bacterial metallothioneins: past, present, and questions for the future," Journal of Biological Inorganic Chemistry, vol. 16, no. 7, pp. 1011-1024, 2011.

[48] M. Mejáre and L. Bülow, "Metal-binding proteins and peptides in bioremediation and phytoremediation of heavy metals," Trends in Biotechnology, vol. 19, no. 2, pp. 67-73, 2001. 

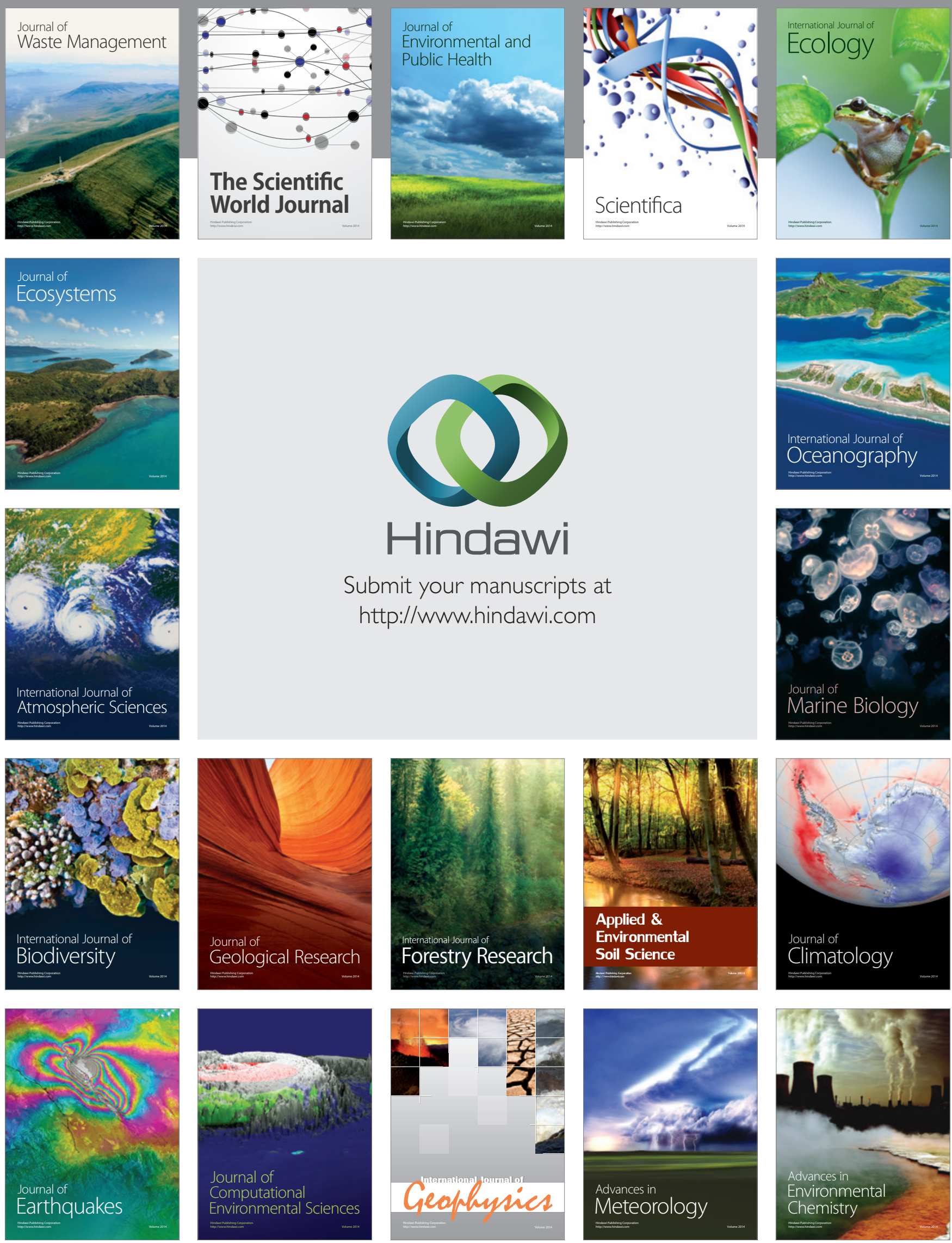